NORMAL PROFESSIONALISM, NEW PARADIGMS AND DEVELOPMENT

by

Robert Chambers

DP 227

December 1986

This paper argues that though development realities and fashions change fast, normal professionalism - the thinking, values, methods and behaviour dominant in a profession or discipline - is stable and conservative. It is linked with core-periphery structures of power and knowledge, reproduced through teaching and defended by specialisation. It values and rewards 'first' biases which are urban, industrial, high technology, male, quantifying, and concerned with things and with the needs and interests of the rich.

New professionalism reverses the values, research methods, roles and power relations of normal professionalism. It puts people first and poor people first of all. The 'last-first' paradigm includes learning from the poor, decentralisation, empowerment, local initiative, and diversity. Development is not by blueprint but by learning process, flexible, iterative and adaptive. New professionalism questions conventional methodologies for appraisal, research, training and managing bureaucracies, and exploits gaps between disciplines as opportunities for the poor. To achieve reversals on a massive scale is now perhaps the greatest challenge facing the development professions.

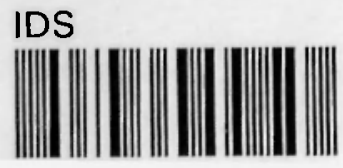




\section{Abbreviations and Definitions}

This paper uses the following abbreviations and meanings:

CPR: common property resource

FSR: farming systems research

IRR: internal rate of return

ITK: indigenous technical knowledge

RRA: rapid rural appraisal

SCBA: social cost-benefit analysis

development professions: professions engaged in development, mainly rural, in or for the Third World. They include administration, engineering, medicine, biological sciences, and social sciences, and are represented in academic disciplines, voluntary agencies, and government organisations. Government departments concerned include administration, agriculture, animal husbandry, community development, cooperation, education, finance, fisheries, forestry, health, irrigation, justice, planning, public works, and water development.

new professionalism: thinking, values, methods and behaviour which reverse many elements of normal professionalism.

normal professionalism: thinking, values, methods and behaviour dominant in professions and disciplines and reflecting 'core' or 'first' biases.

paradigm: a coherent and mutually supporting pattern of concepts, values, methods and action, amenable to wide application. 
NORMAL PROFRSSIONALISM, NEW PARADIGMS AND DEVELOPMENT

'A new paradigm for development seems slowly to be arising and gathering cohesion and support' (Jamieson 1985:5)

'Probably the single most prevalent claim advanced by the proponents of a new paradigm is that they can solve the problems that have led the old one to a crisis...'

(Kuhn 1962:152)

"You are old, Father william", the young man said, and your hair has become very white

And yet you incessantly stand on your head -

Do you think, at your age, it is right?'

(Lewis Carroll, Alice in Wonderland, Ch. 5.)

\section{The setting}

In 1986 the morbid preoccupations of development studies look more than ever justified. There have been some big gains, especially in health and education; but the scale and awfulness of deprivation among the poorer people on the planet, and especially the rural poor in the Third World, remain an outrage. As more countries, and perhaps more people than ever before in recent history, are trapped in downward drifts, development studies, theories and practice have been caught off their guard. The rate of obsolescence of fashions and ideas has accelerated. Some pass so fast that, as with the unsuccessful mountaineers on Rum Doodle (Bowman 1956), high altitude deterioration sets in before acclimatization is complete: prescriptions and policies are abandoned before they have had time to work, or to adapt and adjust and improve in the light of mistakes and experience. We seem never to get there, or get there in time. We are always late, and always out-of-date. But against the gloom and frenetic rise and fall of fashions, can be set one steady trend which augurs well in the long term: the gradual emergence of a new set of ideas about the theory and practice of development, especially but not only in rural development. These are cohering into a new pattern. They generate new agendas for research and action, and demand and support a new professionalism.

These ideas I shall call the new paradigm. I use the word paradigm to mean a coherent and mutually supporting pattern of concepts, values, methods and action, amenable to wide application. Some of the 'new' in this paradigm is old, having been part of the currency of development thinking for some time. What is new is that hitherto disparate strands and tendencies are now fitting into an increasingly clear and powerful, though not fully recognised, pattern. The old development paradigms have left much to be desired. 
The question now is whether the new one can succeed in those domains where the old ones have failed.

\section{Development Professions and Paradigms}

AnY discussion of paradigms invites reference to Thomas Kuhn's illumination of normal science in his book the Structure of Scientific Revolutions (1962). His work and thesis provide a good foil against which to contrast the development professions. Kuhn used 'paradigm' in a restricted sense, to mean 'universally recognised scientific achievements that for a time provide model problems and solutions for a community of practitioners.' (Kuhn 1962:x). Solving these problems constitutes normal science. Kuhn's universe of sciences was consciously limited to the physical sciences such as astronomy, physics and chemistry. Except for passing observations about their similarities and differences, he excluded biology and the social sciences.

In development, however, Kuhn's astronomy, physics and chemistry are either entirely or largely irrelevant, whereas engineering, medicine, biology and the social sciences are involved in both research and in action. Three contrasts between the development professions and sciences and Kuhn's physical sciences are worth noting:

- a changing reality: for the physical (and also biological) sciences there is a strong, though not unchallenged (see sheldrake 1985) assumption that the basic reality does not change, whereas in the development social sciences not only does the reality constantly change (compare sub-Saharan Africa 1970 with 1985), but the rate of change seems to be accelerating.

- new ideas derived from experience: the driving force for change in the physical sciences comes from anomalies and from technologies for observation, measurement and reductionist analysis. In the development field the driving force comes much more from changing reality and from action and experience.

- tolerance of competing ideas: in the biological and social sciences competing paradigms can coexist more easily over long periods (Lamarckian and Darwinian, and neo-lamarckian and neo-Darwinian, theories of evolution; Marxist and neo-classical theories in economics) whereas in the physical sciences more universal paradigm shifts normally take place within a generation.

Consequences for the development social sciences and for development practice are both epistemological and psychological. Epistemologically, with the partial exception of economics, the more interesting and important 
theory is imprecisely articulated and not easily amenable to scientific testing. Psychologically, physical scientists have in the past been deeply committed to paradigms and have faced personal crises with paradigm shifts. Although this can also occur in development, for example with nutrition science's debates over protein and calorie requirements, it is less common: and whatever labels they espouse, most development social scientists are pluralists not deeply committed to interlocked dogma. They do not find it too difficult to adapt their ideas to new conditions. This adaptability, coupled with imprecise theory, means that new paradigms are less needed and less likely to be formulated. It also means that any latent paradigm can go unrecognised or unarticulated for longer.

Rapid change in the reality and lack of widely accepted stable paradigms can lead observers to suppose that development thought and practice are themselves unstable. At two levels this is indeed true. The first, less important instability is academic fashions. These continue but were more marked and frantic in the $1950 \mathrm{~s}$ and $1960 \mathrm{~s}$ when academic luxuries could better be afforded. Many fashions had brief lives. In the softer social sciences, new development subjects ballooned - the diffusion of innovations, systems theory in political science, the development administration movement, the mode of production debate - with an exponential explosion of paper and articles, until, dragged down by the sheer weight of footnotes, the bubble burst or the young dinosaur sank into the mud, according to one's preferred imagery.

The second instability, much more significant, is policy prescriptions for economic development. Sharp shifts in conventional wisdom over short periods are symptoms of a struggle to keep up with diverse and rapidly changing conditions and to learn from experience, as current (1986) stress on policy dialogue, restructuring and market forces illustrates. Whatever else may be uncertain, one can predict with reasonable confidence that ideas about development policy in less developed countries will continue to change fast, and that by the end of the century they will be very different from today.

In such fluid conditions, the use of the word paradigm, with its sense of formal and stable relationships, may be questioned. In the social sciences it is more customary to talk of networks and discourses which accommodate shifts of meaning and content. I shall retain the word paradigm because my argument is that underneath or alongside the sudden switches of vocabulary and the lurches of policy, a new, coherent and consistent set of ideas about development, and especially about rural development practice, has been emerging almost independently, as though in another dimension; and that its gathering support and 
influence have been partly concealed by the overlays of rhetoric and transient policy debate at the macro level.

It is, however, overlaid and hidden by another, more powerful, stable continuity which survives passing academic fashions and rapid changes in policy wisdom. This is to be found in the practical professional side of development and its teaching. This stability has links with academic disciplines and is entrenched in and sustained by the development professions working in government departments. It is part of what I shall call normal professionalism, where each profession can be said to have its normal paradigm.

\section{Normal Professionalism}

Normal professionalism refers to the thinking, values, methods and behaviour dominant in a profession or discipline. There is some analogy with Kuhn's normal science which he saw as 'a strenuous and devoted attempt to force nature into the conceptual boxes supplied by professional education' (Kuhn 1962:5). Like normal science, normal professionalism is conservative. In the development professions, however, normal professionalism encompasses much more than normal science: for it is concerned not just with research, but with action; and its actors are not just in research institutes and universities, but also in international and national organisations, most of them in specialised departments of government (administration, agriculture, animal husbandry, community development, cooperation, education, finance, fisheries, forestry, health, irrigation, justice, planning, public works, water development, and so on). Normal professionalism is a worldwide phenomenon, and has built-in stability from its link with knowledge and power, its reverence for established method, its capacity to reproduce itself, and its defences against threat. It is sustained by the core-periphery structure of knowledge and knowledge generation, by education and training, by organisational hierarchy, and by rewards and career patterns. Let us examine these in turn.

The core-periphery structure of knowledge and knowledgegeneration is so universal that it is habitually overlooked. Those who seek advancement in life seek education and training, and look inwards and upwards for enlightenment and reward. In their careers they move geographically inward to larger and larger urban cores, and simultaneously upward in organisational hierarchies. The capacity to generate knowledge, and the power that goes with that, rise on the gradients from peripheries to cores. Professional rewards (the Nobel prizes being the most extreme example) stem from and reflect the values of the cores, and attract and orient peripheral aspirants like 
iror. filings to their magnets. So whether in medicine, economics, agricultural science, civil engineering, education, or any one of a dozen professions, opportunities are provided by school and university, followed by speciaissed training, to learn what to do in order to move inwards and upwards. Normal professionalism is embodied in the norms, methods and behaviours which are taught, learnt, and rewarded. At the university stage textbooks are the stone tabiets of normal professionalism; later journals and the real or supposed policies of journal editors become more significant, together with promotion boards and professional associations. So people move from Faculties of Agriculture into Departments of Agriculture, from Faculties of Medicine into Government hospitals and health services, from Faculties of Civil Engineering into Departments of Irrigation, Public works, and water Supplies, and from Faculties of Economics into Ministries of Planning and Finance, in each case having been trained to fit and sustain the system.

\section{Conservatism}

The process is conservative. The diploma disease (Dore 1976) drives students to seek degrees or certificates as tickets for jobs and upward movement, and ensures devoted and strenuous learning of whatever is in the textbooks or taught in the classroom. Value is placed on methods for doing things, and then correct observance of those methods. Wherever possible, in deference to the hard sciences and the power of mathematics, these methods involve numbers. Methods are stable. Where they are mathematical and lend themselves to ritual repetition, they are easily accepted and perpetuated. The more they rely on counting and statistics the more methods endure. They survive both because they are useful and because they provide psychological security for those who practise them. So economists learn social cost-benefit analysis; civil engineers learn rules of design; sociologists learn to prepare and analyse questionnaire surveys; agricultural scientists learn to design and lay out experimental plots; psychologists learn to test intelligence and other psychological attributes. Equipped with knowledge of correct methods, those who pass upwards in the system feel confident that they know what to do; and assume, as good normal professionals, that the exercise of their lcarnt skills will establish truth, if they do research, or lead to right actions, if they are involved in development.

Paradoxically, power and flexibility to generate new norms are usually stronger in the cores which are further from the action than in the peripheries which are closer to it. There are notable exceptions like the pioneering work of the University of khon Kaen with rapid rural appraisal (see below). But conservatism at the periphery can take the 
form of fossilisation, preserving the traits of an earlier period. This is built into core-periphery relations, career patterns, and the hierarchy of training. Sometines teachers lecture to their students from their own old notes. They hang onto their old textbooks and hug them for security. The same teaching is then reproduced through successive generations. The English Language Book Society which provides subsidised British textbooks on request from Third World countries is embarrassed by requests for outof-date texts: one has been for a textbook from the 1890s. Or again, staff from Third world universities are trained in the west (or East) and return home with the ideas, orthodoxies, and fashions of those particular years to an isolation in which some then reproduce them for the remainder of their academic lives. Institutions, with their huge inertia, preserve these geological traits. Some Departments of Extension Education in Indian Agricultural Universities, for example, teach concepts and concerns about diffusion of innovations that were current in the late $1950 \mathrm{~s}$ and $1960 \mathrm{~s}$ when their now senior staff spent time in Amerj.car Universities. Today, the book and journal famine in much of SSA is having a similar effect, for different reasons, and with terrible demoralisation of university and other staff: it was reported in 1985 that the University of Nairobi had not been able to order books for five years, the lniversity of Dar es Salaam for seven rears, and the University of Makerere for thirteen years. 1 An externai examiner at Makerere described his experience as entering a time warp, to read essays about Pigou and sthers, and the ecoromic theorjes of earlier decades. The tragic irony of these effects is that debates about developriert become incestuously North-North (like the many neetings ir the $\mathrm{JK}$ in 1985 about sub-Saharan Africa), and coinservative normal professionaiism itself develops a corejoriphery gracient: the pcorer the country and the more isolated its professionals from the rest of the world, the more normal and behind the times (as defined by some in the core) its professionals are liable to be.

\section{Defences}

Normal proiessionalism also maintains itself though a repertoise of defences against discordance and threat. It seeks secirity through specialisation, simplification, rejection, and assimilation.

The first defence is specialisation. This has dimensions of subject and of physical territory. Ecresters stick to trees, and morecver to trees in the forests and forest plantations which they control. Animal specialists stick

1. Since writing this I have heard that in 1985 the Makerere University Library received a large UNESCO grant for purchasing books. 
to animals - the animals about which they have been trained. Agricultural scientists stick to crops, those in which they have specialised. Economists stick to economic analysis in familiar forms. Civil engineers in irrigation stick to design and construction, with a little maintenance, and hold back from operation and management. In such ways, only the familiar is faced. Professions are inbred and look inwards. Normal is narrow.

Simplification is also a defence by limiting concerns and criteria. It often takes the form of a single measure or criterion: the single numeraire that consummates costbenefit analysis; the single objective of 'production' so often proclaimed by agricultural scientists; the achievement of physical targets by civil engineers, or foresters, or water developers; water use efficiency (Bos and Nugteren 1974) by irrigation managers and analysts. But as Oscar wilde once said, 'Truth is never pure and rarely simple': the real world is complex; objectives are multiple; paths of change are not undirectional, and they cannot be predetermined. The single objective or measure gives some security but the many-sided nature of physical and human reality is difficult to keep permanently shut out. So other defences are also needed.

One of these is rejection, taking various forms, including ridicule, even persecution, and boundary definition and maintenance. The best known examples come from the history of science: the persecution of Galileo; the scorn poured by geophysicists on Wegener's theory of continental drift; the definition of parapsychology as being 'unscientific' despite the exceptional scientific rigour of its methods (Barnes 1982:90-3) : and recently the editorial in Nature on Sheldrake's theory of formative causation (which explains anomalies and invites scientific testing), headed 'A book for burning?' (Sheldrake 1985:221-3). The major comparable rejection by the development professions is of the validity of the knowledge of rural people, or indigenous technical knowledge (ITK) (IDS 1979 ; Brokensha et al 1980). Many professionals cannot believe that poor rural people can know anything of consequence. Wegener's theory may have been rejected by geophysicists partly because Wegener earned most of his living as a meteorologist; ${ }^{2}$ ITK is rejected because those who possess

2. This view has been challenged. Wegener held a doctorate in astronomy and did indeed earn his living much of his life as a meteorologist. But Nield (1986) disputes the idea that his being a meteorologist was why his theory was scorned, this being "the one thing even the daftest first-year student manages to remember about the history of the theory of continual drift." Nield implies that Wegener's failure to 
it are worse, not even professionals, but illiterate, low status and poor.

A final normal professional defence against threat or difficulty is assimilation, using familiar methods to modify, describe and often put some sort of number to the discordance, coding it so that it can be fitted on as an extension of the normal paradigm. The familiar formal method then remains paramount by transforming and incorporating the problem. This can be found in every discipline which aspires to hardness. Thus economists respond to the challenge of differential social effects through weightings and shadow pricing; irrigation engineers respond to poor performance on canal irrigation systems by extending physical works, which they know how to construct, to lower and lower parts of the system; doctors respond to the charge that they serve only urban elites by extending health clinics to provide curative services to rural areas; agricultural scientists react to the charge that their green revolution favoured larger farmers by espousing farming systems research which attempts to improve their knowledge of the objectives, conditions and constraints of smaller farmers, and by moving experiments out of their research stations and onto farmers' fields.

In all these instances, the response is 'normal'. It does not threaten the paradigm; instead it extends and even reinforces it. Social cost benefit analysis takes longer and requires more data but ends up with the same familiar percentages and ratios. Irrigation engineers have more work to do but it is of the same kind. Doctors have larger networks of curative institutions to manage, and armies of health workers to train, but they fit into a hierarchy of medical competence and specialisation in which each level deals with what it can, and refers the more professionally exacting cases upwards, reaffirming and reinforcing professional authority. Agricultural scientists through farming systems research appropriate and manipulate the knowledge of farmers, gained through extensive surveys, thereby maintaining control and decision-making about research in their own hands. In ways like these, normal responses maintain or enhance professional power. Reproduced through training and rewards, conservative and well-defended, normal professionalism is very stable.

protect his image was significant. He contrasts the damaging effects of Wegener's unconcealed eccentricity with Charles Dodgson's careful separation of his identity as a mathematician from that of the author of Alice in wonderland. 


\section{Weaknesses}

Normal professionalism has virtues. It provides continuity, coherence and consistency to professional training. Professionals do do their useful things. Civil Engineers do build dams, usually with considerable technical success; doctors do cure the sick; economists do compare alternative projects, and alternative designs within projects; agricultural scientists do breed highyielding varieties. But much is wrong. With the partial exception of medicine, development professions have been rather unself-critical. Yet even superficial introspection reveals that normal professionalism in development is not enough.

Three weaknesses illustrate parts of a larger syndrome. These are gaps, misuse of methods, and prior bias.

Disciplines and professions, both through their nature (generated in cores to fit core categories and to handle core interests and problems), and through their specialisation, leave gaps when applied in peripheries. There is a core elitist assumption that if enough disciplines are mustered and all put to work to study a rural situation or problem in their normal professional way, it will be fully covered. Like searchlights, they will, if there are enough of them, shed dazzling light on all of the target. But this is not so. One example can suffice. Agro-forestry - the growing of trees in interaction with crops and/or animals - is a major component in the farming systems of hundreds of millions of poor farmers. But professional forestry is concerned with trees in forests, agricultural sciences with crops, and animal sciences with animals. There has been no discipline or recognised profession of agroforestry. The journal Agroforestry systems is only a few years old. ICRAF - the International Council for Research in Agroforestry - has been denied membership of the Consultative Group for International Agricultural Research, and in 1985 had only some 18 scientists for the whole world. Agroforestry is a low status activity, the responsibility either of a junior forester isolated in a Ministry of Agriculture, or of a junior agricultural scientist in a Ministry of Forests, or of no one at all.

As with agroforestry, so in general, disciplines, professions and departments are so organised and interlocked that gaps between them have low priority and low status.

Misuse of method is another weakness of normal professionalism. Often misuse makes it possible to manage political pressures; often too, misuse represents the exercise of informal power under the guise of technical 
objectivity. Canal irrigation transmission losses and social cost-benefit analysis present two parallels. Those designing a canal irrigation system are often under political pressure to irrigate a distant area: in one case in India, to accommodate such pressure, the assumption was simply made that there would be no transmission losses, although they often run at 50 per cent or more. Irrigation was made possible on paper and the real problem deferred. Similarly, those responsible for social cost-benefit analysis often face political pressure to produce an acceptable internal rate of return so that a project can qualify for funding. It is easy (though not in the textbooks) to alter assumptions about speed of implementation, volume of future production, and future prices, to produce whatever IRR is required. 'First I decide whether the project is good and worth funding; and then I do the cost-benefit analysis', are typical words of an experienced practitioner. Both irrigation design engineers and economists appraising projects are thus able to bend to political pressures, while at the same time, through the inaccessibility of their calculations and assumptions, maintaining some autonomy and power.

The law of prior bias is another weakness of normal professionalism. According to this, what comes first stands highest, gets most, and sets patterns. This has been enormously influential in development thinking, with mutual reinforcement between overlapping sequences: industrialisation before agriculture in early post-second world war development theory and practice; infrastructure before agricultural and rural development in the evolution of priorities of the World Bank; and the sequence of appraisal, design and construction before operation in every project, even in agriculture. Thus we have hardware before software; and construction before operation. Mathematical skills are also more needed and more used in these earlier stages than in the later ones. Much of this is necessary and inevitable, but the effects are profound and lasting. For methods and patterns developed for the early (hardware, construction, physical) activities persist into and dominate the later (software, operational, social) stages.

Normal professionalism, then, has limitations. Faced with changing conditions, it is conservative, and defended in its narrow specialisations. Generated in and for core conditions, it misses gaps in peripheries, misuses methods, and is biased towards physical construction which comes first in sequences. But this is only what is revealed by a core-periphery, centre-outwards view of normal professionalism. There is another view - reversed, periphery-core, outside to centre, - which reveals more. To understand this we need to examine polar contrasts 
between what is core or 'first' and what is peripheral or 'last'.

Polar Paradigms: First and Last

Power, wealth, knowledge and professionalism are intimately linked. In individual perception, choice and behaviour, deep biases operate. The poles which professionals normally embrace I shall call 'core' or 'first', and those which they normally reject I shall call peripheral or 'last'. These deep biases are not universal. I posit them not as universal laws, but as general tendencies. They can be presented in table 1.

Table 1. Deep Preferences of Normal Professionals

Core or First
power
comfort
wealth
core location
urban
industrial
things
clean, odourless
standarised
tidy
controlled
certainty

Peripheral or Last

weakness
discomfort
poverty
peripheral location
rural
agricultural
people
dirty, smelly
diverse
untidy
uncontrolled
doubt

Normal professionals gravitate towards the core list. Linked and partly overlapping with these deep preferences are preferences for technology, as in Table 2 .

\section{Table 2. Normal Professional Preferences for Technology}

\section{Core or First}

large-scale capital-intensive modern

hardware

inorganic market linked mechanical

developed in core

'high' technology
Peripheral or Last

small-scale

labour-intensive

traditional

software

organic

subsistence linked

human or animal-

powered

developed in

periphery

'low' technology 
These preferences are embodied in a basic ideology in which development is seen as a movement along gradients from peripheral or last towards core or first, and through the spread of core conditions into peripheries. So industry has been valued more than agriculture, large-scale agriculture than small-scale, coffee than cassava, tractors than bullocks or human power, exotic cattle than indigenous, and cattle more than goats, hens or bees. 3 Development has been seen as a process of growth stimulated by transfer of technology, a transfer in one direction, from rich and powerful to poor and weak, from first to last.

Research approaches and methods are similarly polarised, between those that are formal and respectable, with a strong statistical and mathematical content, and those that are informal and looked down upon, which are more qualitative and judgemental. The contrasts are shown in Table 3 .

Normal professional preferences correlate with relative status both within and between professions. Core or first attributes are associated with high professional status and rewards, and peripheral or last attributes are associated with low professional status and rewards. A notional ranking of professional status is presented in Diagram 1.

Taking the three tables of preferences and Diagram 1, many relationships can be identified. Three deserve mention.

First, high status within a profession can be gained or maintained by using the techniques and approaches of another 'high' profession. Examples are 'engineering' in medicine with the spare parts approach of organ transplants, and biotechnology in agriculture using techniques of genetic engineering from physics and microbiology. Low status is similarly transferred: agriculture is generally low status, so that agricultural economics is low in economics, and agricultural engineering is low in engineering.

3. Let me thank Hans Singer for at least 50 clippings and papers about bees sent to me over the past five years ever since he discovered my interest in these 'last' creatures during our work on the second zambia ILO, JASPA mission. 
Second, quantification, mathematical techniques, precise measurement, and power are all linked, and reflected in the high status of physics in the physical sciences, and economics in the social sciences: if economics is the physics of the social sciences econometrics is its nuclear physics. 4 Further, subprofessions or subdisciplines which develop skilled techniques of measurement move upwards: the rise in status of clinical psychologists has been associated with psychological testing and mechanistic behavioural therapies; the status of economists is linked with their command of a mathematical technique in costbenefit analysis; and sociologists aspire to rise through the quantification of questionnaire surveys.

Third, status varies by whether the subjects of professional attention are things (high) or people (low). Medicine deals with people, but the highest status is accorded to those who treat people least as people surgeons, 5 and the lowest to those who not only deal with people but go out beyond the hospital or clinic to work with them in their communities. Similarly, biotechnology is at the top in agriculture, and agricultural extension is the poor relation at the bottom. Going even lower, community health with traditional healers, or agricultural research in which farmers determine priorities and conduct experiments, are beyond the pale, unprofessional, the medical and agricultural equivalents of astrology and parapsychology.

4. There are other similarities. Both nuclear physics and econometrics derive power from arcane mathematics, and both can be dangerous - nuclear physicists by being right and econometricians by being wrong. Both too are liable to a sort of ethical high altitude deterioration, with extreme distancing from the human beings who are affected by their work.

5. It is a reflection of the fearful awe with which I also regard surgeons that I feel it prudent to add a conciliatory footnote that some surgeons do take a considerable interest in their patients. 
Table 3. Preferred research approaches and methods Core or First Peripheral or Last

\begin{tabular}{|c|c|c|}
\hline basic $\operatorname{logic}$ & reductionist & holistic \\
\hline learning mode & $\begin{array}{l}\text { data collection } \\
\text { 'objective' analysis }\end{array}$ & $\begin{array}{l}\text { gaining experience } \\
\text { 'subjective' } \\
\text { judgement }\end{array}$ \\
\hline $\begin{array}{l}\text { information } \\
\text { accepted and } \\
\text { admitted }\end{array}$ & $\begin{array}{l}\text { 'hard' } \\
\text { quantified } \\
\text { precise } \\
\text { visible }\end{array}$ & $\begin{array}{l}\text { 'soft' } \\
\text { qualitative } \\
\text { imprecise } \\
\text { invisible }\end{array}$ \\
\hline methods used & $\begin{array}{l}\text { precise measurement } \\
\text { formal surveys } \\
\text { formal } \\
\text { questionnaires }\end{array}$ & $\begin{array}{l}\text { visual assessment } \\
\text { RRAs } \\
\text { semi-structured } \\
\text { interviewing }\end{array}$ \\
\hline $\begin{array}{l}\text { experimental } \\
\text { conditions }\end{array}$ & $\begin{array}{l}\text { few variables } \\
\text { controlled labora- } \\
\text { tory conditions, } \\
\text { holding much } \\
\text { constant }\end{array}$ & $\begin{array}{l}\text { many variables } \\
\text { uncontrolled, real } \\
\text { conditions } \\
\text { allowing much to } \\
\text { vary }\end{array}$ \\
\hline location & $\begin{array}{l}\text { on-station, } \\
\text { in-laboratory, in } \\
\text { office }\end{array}$ & in field \\
\hline $\begin{array}{l}\text { priorities } \\
\text { determined by }\end{array}$ & professionals & user-clients \\
\hline evaluation by & $\begin{array}{l}\text { peers, research } \\
\text { sponsors }\end{array}$ & user-clients \\
\hline
\end{tabular}




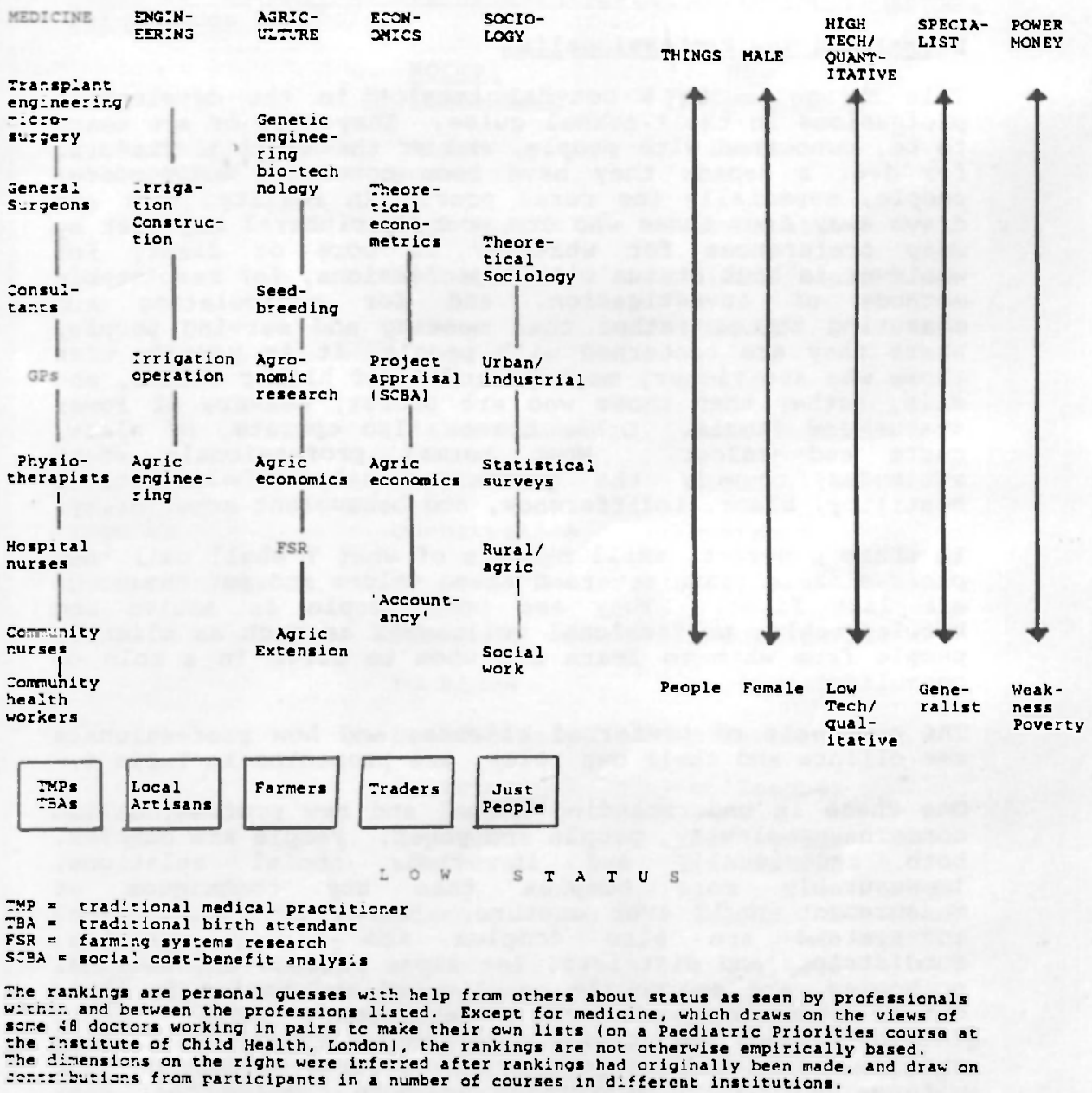


Normal and New Professionalism

This brings us to a central tension in the development professions in their normal guise. They are, or are meant to be, concerned with people, and at the level of rhetoric for over a decade they have been concerned with poorer people, especially the rural poor. In reality, most are drawn away from those who are poor, peripheral and last by deep preferences for whatever is core or first, for whatever is high status within professions, for respectable methods of investigation, and for manipulating and measuring things rather than meeting and serving people. Where they are concerned with people, it is usually with those who are richer, more powerful, of higher status, and male, rather than those who are poorer, weaker, of lower status and female. Other biases also operate, of class, caste and colour. Most normal professionals adopt attitudes towards the poor variously of rejection, hostility, blame, indifference, and benevolent superiority.

In sharp contrast, small numbers of what I shall call 'new professionals' have reversed these values and put those who are last first. They see poor people as active and knowledgeable, professional colleagues as much as clients, people from whom to learn and whom to serve in a role of consultant.

The contrasts of preferred clients, and how professionals see clients and their own roles, are presented in Table 4.

One theme in understanding normal and new professionalism concerns complexity, people and power. People are complex, both individually and in their social relations, immeasurably more complex than any techniques of measurement could ever capture. Rural environments and eco-systems are also complex and highly variable. Subdistricts and districts, let alone regions and national economies, are enormously complicated and varied in their detail when observed from a development angle. Small farming systems are usually more complex than large farming systems. Self-reliant poverty where survival depends on a wide repertoire of activities is more complex than easy affluence. 
Table 4. Normal and New Professionals: Preferred Contacts, Perceotions and Roles

\section{Normal professionals}

Contacts preferred with people who are

$\begin{array}{ll} & \text { high status } \\ \text { educated } & \text { male } \\ \text { adult } & \text { light-skinned } \\ \text { 'last' clients } & \text { obstinately } \\ \text { seen by } & \text { conservative } \\ \text { professionals } & \text { passive } \\ \text { as } & \text { ignorant } \\ & \text { to blame } \\ \text { beneficiaries } & \text { inferiors } \\ \text { professional } & \text { dependent } \\ \text { adopters } & \text { teacher } \\ \text { expert }\end{array}$

New Professionals

'last' weak

low status

illiterate

female

$\operatorname{child}$

dark-skinned

rationally risk-

averse

active

knowledgeable

victims

collaborators

colleagues

autonomous

innovators

learner

consultant

Yet the methods of investigation of modern science simultaneously simplify and keep professionals and people apart. There is a mismatch between statistical methods and people. Counting promotes the counter but demotes the counted. Social cost-benefit analysis, psychological testing, and farm surveys, all distance professionals from people. Knowledge, as so often said, is power. The normal reflex of first professionals faced with last complexity of people, environments, farming systems and so on - is to extract data from and about them, process it, and use it to decide what to do to those people, environments and farming systems. The process is enormously inefficient: 
information is missed, distorted, misunderstood, and often not used. But processing and analysis of data are private activities under the control of professionals: power, in the name of planning and science - the project plan, the district plan, the farm plan, even the national plan - is retained in the hands of the 'first' and expressed in prescriptions for the poor.

Farming systems research (FSR) is an example. Much of the complexity of tropical small farming systems began to be recognised through extremely detailed longitudinal surveys, notably those of David Norman and his colleagues in Northern Nigeria in the late 1960s. The normal professional response to this understanding was to repeat very detailed surveys and analysis in different parts of the world, to try to capture and transfer the complexity of last reality to the domain of first knowledge where decisions could be made. Like national and district planners before them, some agricultural investigators then demanded mountains of data. Mercifully, many of the insights were so simple and easy to obtain, that rapid rural appraisal (RRA) methods could be invented and adopted to shortcut the laborious long-and-dirty route. But even RRA retained power in the hands of the professional. Small farmers were rarely asked what help they would like from scientists. Instead, 'mining' information was made more cost-effective and the scientist still retained decisionmaking power. ${ }^{\circ}$

The new professionalism reverses power relations - 'putting the last first' - in choice of clients, professional values, research methods, and roles. Clients are the poorer and the more deprived, and especially those in rural areas. Professional values are turned around, with shifts towards 'low' technology and software. Research approaches and methods are more holistic and experimental, and located more in field conditions. Roles are reversed, with poor people as teachers and experimenters. Research priorities are determined not by scientists but by the poor themselves. Evaluation is not by peers but by clients. And not surprisingly, the status of many new professionals in the eyes of their peers, is low, if not off the bottom of the scale altogether.

Such reversals may appear extreme. If all professionals adopted them, the modern world as we know it might cease to hold together. There is, though, little danger of that. The point is that whole professional systems are so

6. A summary paragraph cannot do justice to the many forms of FSR. A more detailed review and expansion of this particular argument is presented in Chambers and Jiggins 1986. 
collaborators in the technology development process; initiatives of voluntary and some government agencies in catalysing the formation of groups which then exercise effective demands; the finding that people do more for themselves than expected when they command resources and control their environment. Perhaps the most significant and influential experience, though, has been in south and Southeast Asia with the initiatives which generated the idea of the learning process approach to development (Korten 1980, 1984a and b; Bagadion and F. Korten 1985).

The new development paradigm has four interacting levels: normative; conceptual; empirical; and practical.

The normative level is simple: development should be people-centred (Korten and Klauss 1984; Cernea 1985); people come before things; and poorer people come before the less poor. It is right to put the last first, to give priority to those who are more deprived - the poor, physicaliy weak, vulnerable, isolated and powerless, and to help them change those conditions. It is also right to enable them to identify and demand what they want and need.

The normative level thus supports the reversals of the new professionalism. Women come before men, and children before adults. The weak come before the strong. Professionals become not experts but learners, and poor people their teachers. Priorities are not those projected by professionals, but those perceived by the poor. The goal of development is not growth as defined by normal professionals, but well-being as defined by the poor for themselves. Poor people will define their well-being in different ways. Many are likely to want livelihoods more than employment (Chambers 1983, 1986) where livelihoods mean adequate assets, food, and cash for physical and social wellbeing, mean adequate and security against impoverishment; and they are likely to emphasise both health and consumption. But their priorities will never be uniform.

At the conceptual level, development is not a progress in a single direction, but a process of continuous adaptation, problem-solving and opportunity - exploiting under pressure. Causality is complex and circular, not simple and lineal (Jamieson 1985). Development is not movement towards a fixed goal but continuous adaptation to maximise well-being in changing conditions.

At the empirical level, there are four verifiable elements:

i. conditions are diverse and complex. Physically, environments contain much variation. Resource-poor farms contain, create and exploit micro-environments. Resource-poor farming is usually more diverse in its 
crop-livestock-tree interrelations and its use of biomass than resource-rich farming. Poorer people are often 'foxes' with many different enterprises with which they cobble together a livelihood, doing different things at different seasons, in contrast with better-off people who are more often 'hedgehogs', with one major life support. Diversity and complexity are usually greater for the poorer than for the less poor.

ii. rates of change are accelerating. The rates of ecological change in many parts of the Third World have been insidiously accelerating. The crisis of the Sahel is the outcome of a long decline. The population growth rate in sub-Saharan Africa of over three per cent per annum, with a doubling time of some 23 years, implies unprecedented rates of change in agriculture, livelihoods and social relations; and in other continents too, ecological, economic and social change appear more rapid than before.

iii. poor rural people know a lot (IDS 1979; Brokensha et al 1980; Richards 1985). Indigenous technical knowledge (ITK) is now respected more, and valued not only for its validity and usefulness, but because it is part of the power of the poor. ITK is strong on knowledge of local diversity and complexity, precisely where outsiders' knowledge is weak. In rapid change, its advantages over outsiders' knowledge are even greater.

iv. rural people are capable of self-reliant organisation. This gross generalisation cannot be universal. But that most rural people are more capable of selfreliant organisation than most outsiders are conditioned to believe is supported by much evidence."

The practical level of the paradigm integrates the other three. A practical approach to development embodies reversals, not just of normal professionalism, but of normal centripetal tendencies. The central thrusts of the paradigm here are decentralisation and empowerment. Decentralisation means that resources and discretion are devolved, turning back the inward and upward flows of resources and people. Empowerment means that people, especially poorer people, are enabled to take more control over their lives, and secure a better livelihood with ownership and control of productive assets as one key element. Decentralisation and empowerment enable local

7. See for example the Rural Development Participation Review published by cornell until USAID withdrew its funding support. 
people to exploit the diverse complexities of their own conditions, and to adapt to rapid change. Core programmes spread standardisation over diverse realities: the same crops and treatment are recommended in totally different eco-systems; but in the new paradigm, diverse ecological and socio-economic conditions and personal needs generate their own innovations, find their own solutions, and determine their own pathways.

Decentralisation, empowerment, and adaptation to and exploitation of diverse complexity fit and are part of the clearest, most authoritative and most convincing articulation of practical aspects of the new paradigm, by the Kortens and Bagadion (D. Korten 1980, $1984 \mathrm{a}$ and $\mathrm{b}$ and forthcoming; Bagadion and F. Korten 1985). David Korten has contrasted a blueprint and a learning process approach to development. These correspond closely with normal and new professionalism, except that the new professionalism as advocated in this paper gives more explicit attention to the poorer. Drawing on various D. and F. Korten sources (including personal communications), and with additions, the two paradigms as they apply in approaches to rural development are contrasted in Table 5.

The contrast between blueprint and learning process approaches goes deep. Psychologically, a closed and authoritarian personality fits blueprints: 'I like to know where I stand'; 'we have to know where we are going'; 'objectives must be clearly specified'; 'there must be a plan'. Managerially, the blueprint approach fits the type of organisation which Burns and stalker (1961) call mechanistic - with clear and fixed definition of roles, obligations, procedures and methods, hierarchical authority, punitive management style, and inhibited lateral communications. In contrast, the learning process approach requires and supports an open, democratic personality. It corresponds with the type of organisation Burns and stalker call organic - with flexible and changing definitions of roles, obligations, procedures and methods, collegial authority, and free lateral communications. Mechanistic organisation is more suited to routine activities in a stable environment, organic to adjusting to a changing environment. The contrast is between a linear, rigid, repetitive machine, and a rounded, flexible, adaptive organism. The learning process and the new paradigm of which it is a part, are not mechanical but evolutionary. 


\begin{tabular}{|c|c|c|}
\hline & Blueprint & Eearning Process \\
\hline Idea originates in & capital city & village \\
\hline first steps & $\begin{array}{l}\text { data collection } \\
\text { and pian }\end{array}$ & awareness and action \\
\hline $\operatorname{design}$ & static, by experts & evolving, people involved \\
\hline supporting organisation & $\begin{array}{l}\text { existing, or buile } \\
\text { top down }\end{array}$ & $\begin{array}{l}\text { built bottom-up, with lateral } \\
\text { spread }\end{array}$ \\
\hline matn resources & $\begin{array}{l}\text { central funds and } \\
\text { technicians }\end{array}$ & local people and their assets \\
\hline staff development & classroom, didactic & field-based action learning \\
\hline implenentation & rapid, widespread & $\begin{array}{l}\text { gradual, local, at people's } \\
\text { pace }\end{array}$ \\
\hline management forms & $\begin{array}{l}\text { spending budgets } \\
\text { completing projects } \\
\text { on-time }\end{array}$ & $\begin{array}{l}\text { sustained improvement and } \\
\text { performance }\end{array}$ \\
\hline content of action & standardised & varied \\
\hline communication & $\begin{array}{l}\text { vertical:orders } \\
\text { orders down, reports } \\
\text { up }\end{array}$ & $\begin{array}{l}\text { lateral: mutual learning } \\
\text { and sharing experience }\end{array}$ \\
\hline leadership & positional, changing & personal, sustained \\
\hline evaluation & $\begin{array}{l}\text { external } \\
\text { intermittent }\end{array}$ & internal, continuous \\
\hline error & buried & embraced \\
\hline effects & dependency-creating & empowering \\
\hline $\begin{array}{l}\text { associated with } \\
\text { with }\end{array}$ & $\begin{array}{l}\text { normal profession- } \\
\text { alism }\end{array}$ & new professionalism \\
\hline
\end{tabular}

Source: adapted from David Korten personal communications. 
Finally, the new development paradigm is not just a rural Third World phenomenon. It overlaps and resonates with the alternative movements of rich countries (see eg. Robertson 1983: 90 ff and 1985; and Korten and Klauss 1984). Solutions to the problems of unemployment of the rich world, and of the degraded rotten cores of decaying inner cities, are equally to be sought in decentralisation, empowerment, community involvement, and processes of learning. The reversal of learning from, and working collegially with, clients is one of the rediscovered keys to business success (Peters and Waterman 1982: 156-199) as well as an imperative for anti-poverty development. Decolonisation has many faces beside that of international political relations: decolonisation of minds, institutions, bureaucracy, businesses and professions. The movement for reversals to the new paradigm is not isolated: it is a world-wide convergence.

\section{Some Practical Implications}

The practical implications of the new professionalism and the new paradigm can only be sketched here. They have to be worked through and applied to any development situation. Almost always they will challenge what is being done and the way it is being done. Almost always they will meet opposition. But there are now enough examples of successful professional reversals and successful implementation of the new approaches to suggest that they are feasible on a much wider scale.

Some needs, successes and opportunities can be outlined under six headings representing obvious points of entry. These indicate only some of many practical implications.

\section{i. professional methodologies}

The new paradigm and the new professionalism will probably challenge many normal professional methodologies. Two examples can suffice, one from economics, and one from agriculture.

Social cost-benefit analysis (SCBA) is deeply entrenched in the normal professionalism of economics. Whatever the qualifications about weightings for distribution effects, it fits the philosophy which puts growth before people, and which still dominates. (The declaration from the 1985 Bonn summit uses the word growth 12 times in the first five pages (TOES 1985)). SCBA is also the activity which noneconomists most associate with economists. It is taught world-wide. The old joke that the literature on SCBA had taken off into self-sustaining growth even if economies had not is dated by its Rostovian allusion even if it remains as apposite as ever, as textbooks go into their nth 
editions. It is taught in a core of development cores, the Economic Development Institute of the World Bank, reinforcing the high status it anyway enjoys through its mathematical methods and well defined routines. But SCBA neither puts the poorer people first nor even puts people first. The classic and magisterial guide The Economic Analysis of Agricultural projects (Gittinger 1982) is in the blueprint mode, identifying projects as 'the cutting edge of development'. Other objectives are recognised but income maximisation is given priority, with the justification that 'in most developing countries increased income is probably the single most important objective of individual economic effort, and increased national income is probably the most important objective of national economic policy' (Gittinger 1982:45). Weightings for distribution effects are possible, but the main concern is production and income: thinking starts with income and too easily ends with the internal rate of return.

There are, however, alternatives or complements to SCBA. one is an economic decision matrix (Carruthers and clayton 1977) which lays out project alternatives and rates them according to, not just economic internal rate of return, but also other criteria including jobs created per $\$ 1,000$ investment, proportion of project income to the poorest 20 per cent of the population, location in a priority development area and so on. Another is Charles Elliott's (1982) analysis of who would gain and who would lose from alternative development measures for the Dal Lake in Kashmir. This lists nine interest groups and compares their gains and losses in relation to project cost and other factors. But we are so profoundly conditioned to the growth philosophy that the germs of alternative methods like these may be dismissed almost out of hand. One wonders whether we are waiting for an economic Einstein to demolish and reorder the Newtonian edifice of SCBA, or at least set up an alternative, or whether it will have to be a Wegener trained and based outside the discipline who dares to articulate the obvious.

The second example is agricultural research methodology. Normal agricultural research is reductionist, measuring a few variables in controlled conditions. It also usually has access to unlimited inputs. The results often suit resource-rich farmers, whose farming and access conditions are similar, and do not suit resource-poor farmers whose farming and access conditions are different. Resource-poor farming systems are also often more complex. To meet this problem, farming systems research is an attempt by outsiders to gain enough understanding to identify small farm, and sometimes resource-poor farm, research priorities. But resource-poor farmers often have a good sense of what they need and are themselves innovating and experimenting. An alternative last-first paradigm is 
emerging through work such as that of Robert Rhoades and his colleagues at the International Potato Centre in Peru and of Jacqueline Ashby in Colombia. The new last-first method starts with farmers and enables them to specify priorities, with scientists as consultants, and strengthens, farmers' own experiments, with reversals of role (scientists learn from farmers), of location (on-farm instead of on-station) and of evaluation (by farmers instead of by scientists' peers) (Chambers and Ghildyal 1985).

\section{ii. rapid appraisal}

Rapid appraisal, more usually rapid rural appraisal (RRA), is the term used to describe methods for outsiders to learn about conditions in ways which are cost-effective in tradeoffs between amount, relevance, accuracy, timeliness and actual use of information. There is now a large literature 8 a theoretical underpinning, and a growing body of practitioners, with the University of Khon Kaen in Thailand as a pioneering centre.

The harmony between RRA and the new development paradigm has been pointed out and elaborated by Jamieson (1985). He considers that the normal internalised set of rules for determining validity are much more 'arbitrary, culturebound and outmoded than is commonly recognised. Statistical validation techniques are certainly useful tools, but there is nothing magical about them and the claim to scientific rigour so frequently invoked by their use is often a spurious one'.

RRA in contrast is flexible, exploratory, interactive and iterative. Increasingly it uses 'triangulation', checking information in several different ways. The techniques for gaining insights have developed in the past five years, and Conway's (1985) methods for ordering and presenting information have made what seems a quantum leap. For the new professionalism, and the new paradigm, RRA has four principal advantages.

First, in conditions of accelerating change in rural conditions, it provides for faster and fuller feedback and learning for professionals from face-to-face contact,

8. An annotated bibliography is in preparation under the supervision of Christopher Gibbs of the East-West Centre, Haiwail. The papers of the International Conference on Rapid Rural Appraisal held at the University of Khon kaen are the most up-to-date theoretical and practical statement, and will be published. Appendix B captures some of the consensus of RRA practitioners at the khon kaen conference. 
sparing their time and coming quickly to a conclusion. A Nigerian investigation of the underutilisation of public sector health facilities using focus groups took two weeks in mid-march 1985 and was presented at a final report in April (Attah 1985). RRA techniques are increasingly used in farming systems research at various stages in research and extension process (Galt 1985). They fit the cybernetic, adaptive model of development.

Second, it provides a quality, depth and range of insight impossible with questionnaire surveys. Instead of imposing outsiders' categories on their reality, good RRA allows the categories to come from rural people and the reality. Rapid does not mean second best. To the contrary, at the International Conference on Rapid Rural Appraisal at the University of Khon Kaen in 1985 it was repeatedly emphasised that RRA can generate a quality of information and insight of a different order to more conventional methods.

Third, it is a means of professional reorientation. It has been found effective for professional 'flips' to discover the interest, pleasure and excitement of learning from rural people instead of teaching them. It is a technique for encouraging and forming new professionals.

Fourth, by its sparing demands on time, it makes space to let in the poorer people. So often they are at the end of the line, the last to be met or to be learnt from. RRA, by avoiding the biases and rush of rural development tourism, the distancing of questionnaires, and the overcommitment of large surveys, can bring professionals face-to-face to learn from the rural poor.

\section{iii. gaps as centres 9}

Reversals from first to last point to gaps in professional knowledge and activity. More is known by professionals about the things of the rich than about the things of the poor. Main line disciplinary work in, say, agriculture, animal husbandry or forestry have in the past fitted the needs of those who are better off and the benefits have been largely appropriated by them. The gaps left by normal professionalism often correspond with the resources and interests of the poor where the potentials of modern science have been little applied. So new 'last' technology and new patterns of gap development offer scope for enabling poor rural people to command better livelihoods.

9. These points are presented at greater length in IDS Annual Report 1984: 40-2. 
Many examples could be given. Three with big potential for the poor are agroforestry, uses of biomass for energy, and common property resources (CPRS). First, agroforestry as we have seen falls in the gaps between agriculture, forestry and animal husbandry. Second, the energy crisis has been seen, in normal professional terms, as a problem for the urban and the rich, not as an opportunity for the rural and poor. Rising values of biomass for energy present opportunities for new livelihoods, yet there is no international centre for energy or biomass-based livelihoods for the poor, nor, as far as I know, has one ever been considered. Third, CPRs have received rather little attention. Almost all rural research in South Asia at least, has concentrated on private property resources, especially farming. But CPRs, as Jodha (1983) has shown, can be of much greater proportional importance for the livelihoods of poorer rural people than for those of the less poor.

\section{iv. bureaucratic programmes}

The new paradigm appears incompatible with large-scale bureaucratic programmes which tend to be standardised, hierarchical, insensitive to local conditions, and biased towards the less poor. There are, however, ways in which large-scale programmes can serve the new paradigm. Three will be mentioned.

The firs: is through wide, preferably universal, coverage by a simple standardised programme which transfers power or resources to the poor, or reduces their vulnerability. An early example was the worldwide vaccination which eliminated smallpox. It was based on a very simple technique with 3 hollow needle which held the right amount of vaccine, and was easy to implement. More recently, UNICEF's GOBI programme, though it has some less simple elements, has similar potential. It puts children, and their mothers, first. Immunisation reduces vulnerability, and power is transferred to mothers through their understanding of growth charts, and their learning to administer oral rehydration to their children. Above all breastfeeding not only reduces vulnerability to disease but returns self-reliance and control to mothers.

Second, large-scale programmes, like the Employment Guarantee Scheme in Maharashtra in India, can be mounted to provide work at minimum wages when it is needed. The low wages dutomatically select for the poor - the less poor are not interested; and the system of demand, which gives groups of people the right to demand work or to be paid anyway, ensures that it is precisely when poor people feel the need that they can command income. Much the same can be true of responsive food-for-work programmes. 
A third opportunity is bureaucratic reorientation (BRO) (D. Korten and Uphoff 1981; Bagadion and F. Korten 1985). This can take the form of transforming a hierarchical traditional bureaucracy into a 'learning organisation'. The reorientation of the National Irrigation Administration in the Philippines over almost a decade is a model. Some of the key elements were continuity of committed leadership, financial and other support from an outside catalyst, a working group which included non-Government professionals, a built-in research and learning capacity, and adoption of the learning approach. In this the sequence is learning to be effective, learning to be efficient, and only then, learning to expand (Korten 1984b 183). This approach has been adopted also for community forestry in the Philippines, for four programmes in Indonesia and for two in Thailand.

\section{v. voluntary agencies}

Voluntary agencies are well placed to develop and implement the new paradigm. Many already put the last first. In this, they face problems of scale, staff numbers and replication. Some of the best initiatives are staffintensive, for instance the formation of small groups of the poor at village level as promoted by OXFAM in India. outstanding voluntary agencies have managed both to empower the poor and to grow without losing their focus. Examples are BRAC (the Bangladesh Rural Advancement Committee), PROSHIKA, and the Grameen Bank - all in Bangladesh, and the Working Women's Forum in South India. The Working Women's Forum has as its members only very poor women for whom it negotiates small loans. It has achieved many simultaneous reversals to create and sustain an enthusiastic and committed counterculture. This stands on their heads the normal biases of class, caste, gender, learning and hierarchy (the organisation chart has the members on top and the President at the bottom).

The practical challenge for many voluntary agencies is threefold: to maintain a commitment to the poor; to proceed through David Korten's three stages of learning to be effective, to be efficient and to expand; and developing new approaches which can then be transferred to large government bureaucracies, as attempted with primary health care. To do that, most voluntary agencies need themselves to become more professional. 


\section{vi. professional training and rewards}

Finally, a shift to the new professionalism and the lastfirst paradigm requires changes in professional training and rewards. The difficulty here is to find 'soft spots', points at which leverage can be exercised. University textbooks, training course materials and syllabi, policies of journal editors, prizes and other forms of recognition for good last-first work - these are some of the options. But again and again change depends on individual professionals and their decisions. Many are trapped in normal professional hierarchies where they have little room for manoeuvre. But most have some scope for some change, and many can find allies who feel likewise and can help. For major shifts do not come suddenly by fiat, though fiats help, but gradually through a multitude of small decisions and actions which together build up into a movement.

\section{Conclusion}

At the head of this paper, I quoted Thomas Kuhn: 'Probably the singie most prevalent claim advanced by the proponents of a new paradigm is that they can solve the problems that have led the old one to a crisis ...' (Kuhn 1962:152).

The new paradigm which I have sketched is primarily derived from and intended for rural development. Eut it can be extended to include reversals in international relation and exchanges, and the new professionals are not only those who work in the peripheries, but also those who support them in the cores.

To what extent the new paradigm can solve the problems which have led deveioprient to a crisis depends on people, on professionals. They are the key. The problem is not 'them' (the poor), but 'us' (the not poor). The massive reversals reeded to eliminate the worst deprivation need professionals to fight within the structures in which they find themselves. Reversals to fight for are well known and include changes in adverse trends in terms of trade, in the operation of interrational and bilateral organisations at the macro level, and in policy within both developed and less developed countries. Rut the sasie isślue is power. Those with fower - 'us' - do not easily give it up. The challenge then is to find ways in which more and more of those who are powerful and privileged can be enabled to work to start and strengthen processes which in turn enable and empower those who are weak and deprived.

As I have argued this requires new professionals who, in Herbert Butterfield's phrase, (1949) 'take hold of the other end of the stick', who stand convention on its head, who put people first and poor people first of all. 
Normal professionals face the core and turn their backs upon the poor New ones by standing on their head face the periphery instead.

By doing this they may, like Father william, free themselves from the mental prison of the normal view. With this reversed vision they may see opening up an intellectually exciting agenda of research and, more important, a practically challenging agenda of action.

To make reversals requires little of a desk-bound academic. It is harder, and takes courage, for those others who combine analysis with engagement in practical affairs. But there are role models, people who have combined excellence in their professional work with a rare and original vision and a commitment to creating institutions to make the world a better place. Fritz Schumacher is one, stigmatised as eccentric, yet influencing all development professions with the message of his three simple words (1973), his writing, and the organisation he left behind. Hans singer is another, at one time branded as 'revolutionary and even subversive' for his prophetic (1950) views on worsening terms of trade for primary producers, yet profoundly influencing development economics with his reversals of view, and policy and practice with his intellectually creative role in the initiation of UN agencies for development. There have always been new professionals, and when they succeed, as Schumacher and singer have done, in changing the course of thought and action, it is easy later to underestimate their originality and achievement. Without them, much that we take for granted would not have happened. The question is how to multiply such people.

Whether the new professionalism and the new paradigm can spread and transform the development process on anything like the scale needed cannot be foreseen. But there is less and less reason to doubt that they could. Parallel efforts are needed - conversions of the cores and successes in the peripheries. New professionals, wherever they are, have support from much of the rhetoric of development, but the inertia of the normal has been shifted but little. If the new professionalism and the new paradigm do not become a mainstream in reality, the end of the century may see deprivation more awful in depth and scale even than today. But if they gather momentum and become a movement, there will be hope of major changes for the better. To achieve that momentum and movement is now, as we move towards the 21st century, perhaps the greatest challenge facing the development professions. 


\section{References}

Ashby, Jacqueline, 1984, 'Participation of Small Farmers in Technology Assessment', International Fertiliser Development Center

Attah, E.B, 1985, 'Underutilisation of Public Sector Health Facilities in Imo state, Nigeria: a study with focus groups', Final Report, April

Bagadion, Benjamin U. and Frances F. Korten, 1985, 'Developing Irrigators' Organisations: A Learning Process Approach', in M. Cernea (ed.) putting People First, OUP for the world Bank.

Barnes, Barry, 1982, T.S. Kuhn and Social Science, Macmillan, London and Basingstoke

Bos, M.G. and J. Nugteren, 1974, on Irrigation Efficiencies, International Institute for Land Reclamation and Improvement, Wageningen

Bowman, W.E. 1956, The Ascent of Rum Doodle, MacDonald and Company

Brokensha, David, D.M. Warren and Oswald Werner (eds), 1980, Indigenous Knowledge Systems and Development, University Press of America, Lanham MD20801

Burns, Tom and G.M. Stalker, 1961, The Management of Innovation, Tavistock Publications, London

Butterfield, Herbert, 1949, The origins of Modern Science, Bell and Sons, London

Carruthers, I.D. and E.S. Clayton, 1977, 'Ex-post evaluation of agricultural projects', Journal of Agricultural Economics, vol 28 , no 3

Cernea, Michael (ed)., 1985, Putting People First: Sociological Variables in Rural Development, OUP for the World Bank

Chambers, Robert, 1983, Rural Development: Putting the Last First, Longman, Harlow

Chambers, Robert, 1985, 'Putting 'last' thinking first: a professional revolution', in Altaf Gauhar (ed.), Third World Affairs 1985. Third World Foundation for Social and Economic Studies, London, pp. 78-94 
Chambers, Robert and B.P. Ghildyal, 1985, 'Agricultural Research for Resource-Poor Farmers: the Farmer-First-andLast Model', Agricultural Administration, 20, 1 pp. 1-30, (Also Discussion Paper 203, IDS

Chambers, Robert and Janice Jiggins, 1986, 'Agricultural Research for Resource - Poor Farmers : a Parsimonious Paradigm', Discussion Paper 220, IDS

Chambers, Robert and B.P. Ghildyal, 1985, 'Agricultural Research for Resource - Poor Farmers: the Farmer-Firstand-Last Model', Agricultural Administration, 20,1 pp. 130, (Also Discussion Paper 203, IDS, Sussex)

Chambers, Robert, 1986, 'Sustainable Livelihood Thinking : an Approach to Poverty, Environment and Development', IDS, Sussex, June

Conway, Gordon, 1985, Rapid Appraisal for Agrosystem Analysis, Aga Khan Rural Support programme, Babar Road, Gilgit, Northern Pakistan and Centre for Environmental Technology, Imperial College of Science and Technology, London september

Dore, Ronald, 1976, The Diploma Disease: Education, Qualification and Development, George Allen and Unwin, London

Elliott, Charles, 1982, 'The Political Economy of Sewage', Mazingira, vol 6, no 4, pp. 44-56.

Galt, Daniel L. 1985, 'How Rapid Rural Appraisal and Other Socio-economic Diagnostic Techniques Fit into the Cyclic FSR/E Process', paper for the International Conference on Rapid Rural Appraisal, Faculty of Agriculture, University of Khon Kaen, Thailand, 2-5 September

Gittinger, Price, 1982, Economic Analysis of Agricultural Projects, Johns Hopkins Press, Baltimore and London

IDS, 1979, 'Rural Development: Whose Knowledge Counts?' IDS Bulletin, vol 10, no 2, IDS, Sussex

Jamieson, Neil, 1985, 'The Paradigmatic Significance of Rapid Rural Appraisal', paper for the International Conference on Rapid Rural Appraisal, Faculty of Agriculture, University of Khon Kaen, Khon Kaen, Thailand, 2-5 september

Jodha, N.S., 1983, 'Market Forces and Erosion of Common Property Resources', paper presented at the International Workshop on Agricultural Markets in the Semi-Arid Tropics, ICRISAT Centre, Patancheru, Andhra Pradesh, 2429 October 
Korten, D.C., 1980, 'Community organisation and rural development: a learning process approach', Public Administration Review, Vol. 40, Sept-Oct, pp. 480-510

Korten, D.C., 1984a, 'People-centred development: toward a framework', in D.C. Korten and R. Klauss (eds.), PeopleCentered Development, Kumarian Press, west Hartford (Conn) pp299-309

Korten, D.C.,1984b, 'Rural development programming: the learning process approach', in D.C. Korten and R. Klauss (eds.) People-Centered Development, pp 176-88

Korten, David C.and R. Klauss (eds.)., 1984, PeopleCentered Development: Contribution toward Theory and Planning Frameworks. Kumarian Press, West Hartford, (Conn.)

Korten, David and Uphoff, 1981, 'Bureaucratic Reorientation for Participatory Rural Development', NASPAA Working Paper No. 1, National Association of Schools of Public Affairs and Administration, Washington, D.C.

Korten, David, forthcoming, Community Management, Kumarian Press, West Hartford (Conn.)

Kuhn, Thomas, 1962, The structure of Scientific Revolutions, University of Chicago Press

Matlon, P., R. Cantrell, D. King, and M. Benoit-Cattin (eds.),1984, Coming Full Circle: Farmers Participation in the Development of Technology, International Development Research Centre, Ottawa

Needham, Rodney (ed.), 1973, Right and Left: Essays on Dual Symbolic Classification, University of Chicago Press

Nield,'Ted, 1986, 'Peeling off the labels', New Scientist, 2 January, p. 47

Peters, Thomas J. and Robert H. Waterman, 1982, In Search of Excellence: Lessons from America's Best-Run Companies, Harper and Row, New York

Rhoades, Robert E., 1984a, 'Tecnicista versus campesinista: praxis and theory of farmer involvement in agricultural research', in Matlon et al. (eds). Coming Full Circle: Farmers' Participation in the Development of Technology. International Development Research Centre, Ottawa pp. $139-150$

1984b, Breaking New Ground: Agricultural Anthropology. International Potato Center, Lima 
Rhoades, Robert and Robert Booth, 1982, 'Farmer-back-tofarmer: a model for generating acceptable agricultural technology', Agricultural Administration. vol 11, pp 12737

Richards, Paul, 1985, Indiqenous Aqricultural Revolution, Hutchinson, London

Robertson, James, 1983, The Sane Alternative : a Choice of Futures, James Robertson, The Old Bakehouse, Cholsey, nr. Walling ford, oxford

1985, Future Work: Jobs, self-employment and
Seisure after the industrial aqe, Gower/Maurice Temple
Smith, Aldershot

Schumacher, E.F., 1973, Small is Beautiful: a study of economics as if people mattered. Blond and Briggs, London

Sheldrake, Rupert, 1985, A New Science of Life: The Hypothesis of Formative Causation, Anthony Blond, London (Second edition)

Singer, H. 1950, 'Distribution of Gains between Investing and Borrowing Countries', American Economic Review, Papers and Proceedings, Vol. 40, (May) 1950, pp. 473-85

TOES, 1985, New Economics 85, Report and summary of the Other Economic Summit (TOES) 1985, The other Economic Summit, 42 Warriner Gardens, London Sw11 4DU 


\section{Appendix A Dual Schemes and the New Paradigm}

Dual schemes of dichotomies with parallel polar lists are used in this paper to illustrate and sharpen points. They have weaknesses. They can suggest that choices are 'either or,' or that they are zero sum. But neither is necessarily the case. The search for the optimal often leads to positive sum solutions which combine opposites in new ways. But to combine them well it is best to pull them apart to see the nature of the choice, and then offset the biases to the 'first'.

Dual schemes anyway seem rooted in human thought, both traditional and recent, as two books show.

One is Right and Left: Essays on Dual Symbolic Classification, edited by Rodney Needham (1973). This shows that some traditional right and left symbolism associates 'first' characteristics with the right hand, men and maleness, and 'Iast' characteristics with the left hand, women, and femaleness. Chapters of Needham's book by different authors, show similarities between right and left symbolism among the Mugwe, Kaguru, Mapuche, Gogo, Nyoro and Lugbara (pages 116, 151, 192-6, 279-80, 328 and 387 respectively). of these all are East African except the Mapuche, who are Chilean. Among the more common contrasted symbolic differences are:

\section{Right}

Male, men

White

older people

Purity

Daytime, light

Wealth, abundance

r.15-

Strength, superiority

Farmers

Home, land of the people
Left

Female, women

Black

Younger people

Impurity

Night, darkness

Poverty, hunger

LeaLis

Weakness, inferiority

Hunters

Bush, other places 
of particular interest from a first-last perspective are:

\section{Right}

first

first wife

clever

initiated

regular or stable

cooked

brewing

bush clearing

domesticated animals

cattle

cultivation

\section{Left}

second

(Kaguru)

co-wife

(Meru)

stupid

(Gogo)

uninitiated

(Kaguru)

difficult to control (Kaguru)

uncooked

(Kaguru)

cooking

(Nyoro)

seed planting

(Gogo)

wild animals

(Lugbara)

chickens, sheep

(Nyoro)

honey-collecting

(Meru)

Whether these associations have some universal validity in human experience and consciousness is an open question. As soon as a generalisation begins to form, an exception may be found. There are for example, differences over whether the sun and moon are masculine or feminine (even between French and German). In Chinese culture, the yin belongs to the female and is right, while the yang belongs to the male and is left. All the same it is striking how commonly associations are found of male-right-white-light-purestrong-superior-good, and female-left-black-dark-impureweak-inferior-bad.

It is fascinating to set these associations against a contemporary dual classification, which has strong resonance with first-last, as well as with right-left. In his book Future Work (1985), James Robertson identifies two contrasting visions of post-industrial society which have emerged in the last few years. The HE vision is HyperExpansionist, while the SHE vision is Sane, Humane, Ecological. The main values and tendencies are: 


\begin{tabular}{|c|c|}
\hline quantitative values and goals & $\begin{array}{l}\text { qualitative values an } \\
\text { goals }\end{array}$ \\
\hline economic growth & human development \\
\hline $\begin{array}{l}\text { organisational values and } \\
\text { goals }\end{array}$ & $\begin{array}{l}\text { personal and inter- } \\
\text { personal values and } \\
\text { goals }\end{array}$ \\
\hline money values & $\begin{array}{l}\text { real needs and } \\
\text { aspirations }\end{array}$ \\
\hline contractual relationships & $\begin{array}{l}\text { mutual exchange } \\
\text { relationships }\end{array}$ \\
\hline $\begin{array}{l}\text { intellectual, rational, } \\
\text { detached }\end{array}$ & $\begin{array}{l}\text { intuitive, experi- } \\
\text { ential, empathetic }\end{array}$ \\
\hline masculine priorities & feminine priorities \\
\hline specialisation/helplessness & al1-round competence \\
\hline technocracy/dependency & self-reliance \\
\hline centralising & local \\
\hline urban & country-wide \\
\hline European & planetary \\
\hline anthropocentric & ecological \\
\hline
\end{tabular}

(Robertson 1985:5)

Dual schemes are not the only way of thinking and classifying, but they are deeply rooted. They sharpen insight into attitudes and options. Whether the columns are right-left, HE-SHE, or first-last, they serve to identify interlocked clusters of biases against the weak and the poor and the things which are important to them, to question the validity of 'normal' first development, and to strengthen the case for reversals. 


\begin{tabular}{|c|c|c|}
\hline \multirow[t]{2}{*}{ Basic Principles } & Implications for Research Methodologies & \multirow[t]{2}{*}{ Choice of Methudolegieal upt suny } \\
\hline & PROVEN METHODS & \\
\hline $\begin{array}{l}\text { I - Emphasis on Contexts } \\
\text { (Relationships) } \\
\text { - Use of Local Knowledge } \\
\text { and Conceptual systems } \\
\text { - Analysis as Close to } \\
\text { Source as Possible }\end{array}$ & $\begin{array}{l}\text { - Semi structured interviewing } \\
\text { - Working for more than "answers" to questlons } \\
\text { - Generate progressive improvement in tentative } \\
\text { hypotheses } \\
\text { - Data analysis by Field Researchers }\end{array}$ & 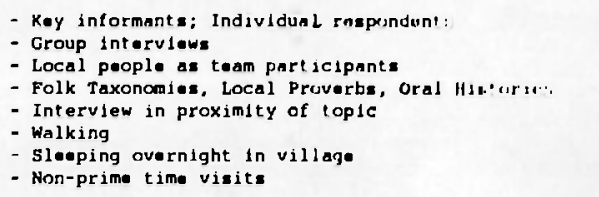 \\
\hline $\begin{aligned} \text { II - } & \text { Triangulation } \\
& \text { (Multiple Checks) }\end{aligned}$ & $\begin{array}{l}\text { - Use of other methodologies } \\
\text { - Information collection in advance } \\
\text { - Direct observation }\end{array}$ & 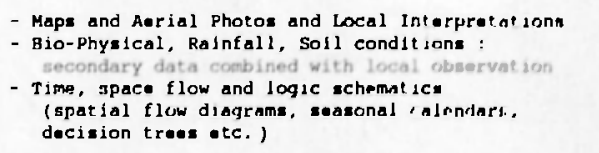 \\
\hline $\begin{array}{l}\text { III- Interactive } \\
\text { - Exploratory } \\
\text { - Rapid }\end{array}$ & $\begin{array}{l}\text { - Structure of time for team interaction } \\
\text { - Sufficient time to return to topic for more } \\
\text { information } \\
\text { - Use of recurring rapid appraisals } \\
\text { - Producing tentative hypotheses and working to } \\
\text { refine them } \\
\text { - Initially considering all aspects of the system } \\
\text { through rough approximation and moving towards } \\
\text { definition of model } \\
\text { - Time period - f few days to a few weeks } \\
\text { - Preparation of the report as part of the appraisal }\end{array}$ & 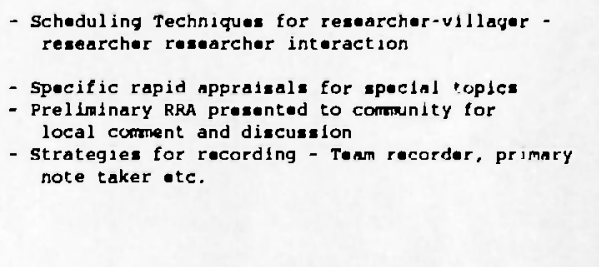 \\
\hline Iv - Flexible & $\begin{array}{l}\text { - Selection from among wide range of me hological } \\
\text { options tools, techniques: and ability to } \\
\text { shift and revise as work progress through } \\
\text { conscious judgements and critical evaluations }\end{array}$ & $\begin{array}{l}\text { - Team meeting in tield to explicitly asia.... prograss } \\
\text { and change directions and mathoda }\end{array}$ \\
\hline
\end{tabular}

SOURCE: Adapted from notes of working group at the International Conference on Rapid Rural Appraisal. Khon Kaen University, Khon Karn, Thasl,als, 2-5 September 1985 